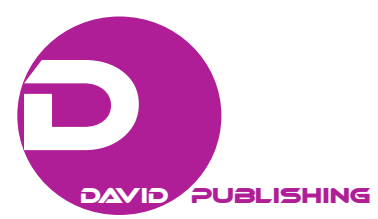

\title{
Threshold Effects in the Capital Account Liberalization and Foreign Direct Investment Relationship
}

\author{
Gammoudi Mouna, Cherif Mondher \\ Université de Reims, Région Champagne-Ardenne, France
}

\begin{abstract}
This paper examines how capital account liberalization (CAL) affects foreign direct investment (FDI) inflows. Authors use a dynamic panel model encompassing 14 Middle East countries over the period from 1985 to 2009. The findings suggest that countries that are able to reap the benefits of the capital openness policy satisfy certain threshold conditions regarding the level of financial development and institutional quality. Thus to promote FDI, governments in this region should develop a set of policies that not only focus on financial openness, but also on the improvement of the financial system and legal institutions.
\end{abstract}

Keywords: capital account liberalization (CAL), foreign direct investment (FDI), institutional quality, system GMM estimator

\section{Introduction}

Capital account liberalization (CAL) has been one of the most important economic policies recommended to developing countries for economic growth. Since the early 1990s, many countries in the Middle East have established the measures of CAL to attract capital flows mainly foreign direct investment (FDI), which is understood to be a major antecedent to economic development. Although, all members of them have witnessed a substantial increase in the FDI inflows from 1985 to 2009 (Figure 1), it have been and continue to be poor in comparison with the world and other developing regions. Furthermore, Figure 2 indicates a wide disparity in FDI inflows and a notable difference in the process of CAL among Middle East countries. The question that arises then is whether and under what conditions capital account policy promotes FDI. A few empirical studies have been conducted to investigate this issue, which is still an open question until to date.

Studies have failed to establish a stable relation between capital account openness and FDI growth. Some of them have found a positive impact of capital openness on FDI (Gastanaga, Nugent, \& Pashamova, 1998) and support the notion that countries with relatively liberalized capital accounts attracted more FDI inflows than countries that are more closed. Butkiewicz and Yanikkaya (2008) reached the same result and concluded in their study that capital restrictions reduce the benefits of FDI on growth in developing countries. Others have doubted the robustness of this impact; Asiedu and Lien (2004) employed panel data for 96 countries over the period from 1970 to 2000 and found that the impact of capital controls on FDI varies by region and has

Gammoudi Mouna, Ph.D. student in economics, Université de Reims, Région Champagne-Ardenne, France.

Cherif Mondher, Ph.D., professor, Université de Reims, Région Champagne-Ardenne, France.

Correspondence concerning this article should be addressed to Gammoudi Mouna, Université de Reims Champagne Ardenne UFR des Sciences Economiques, Sociales et de Gestion 57 bis, rue Pierre Taittinger 51096 Reims Cedex, France. E-mail: mouna.gammoudi@univ-reims.fr;mounagammoudi@yahoo.fr. 
changed over time and proved that capital controls have no effect on FDI to Sub-Saharan Africa and the Middle East, but affect FDI to East Asia and Latin America adversely. This controversy has prompted research on the evaluation of the possible pre-conditions under which CAL may spur FDI. From a theoretical point of view, countries must reach a certain threshold in terms of institutional and economic development before they can expect to benefit the CAL (Chinn \& Ito, 2008; Noy \& Vu, 2007; Alfaro, Kalemli-Ozcan, \& Volosovych, 2005). Broadly speaking, the most important preconditions for moving to CAL are: financial market development, institutional quality, and macroeconomic stability. However, very little attention has been paid by scholars to this argument. Recently, some empirical studies conducted by (Noy \& Vu, 2007, Cherif, Ben, Goaied, \& Kamer, 2011; Okada, 2013) examine how the role of institutional quality as a key factor in explaining the mixed results in the effect of CAL on FDI inflows has reached more positive conclusions.
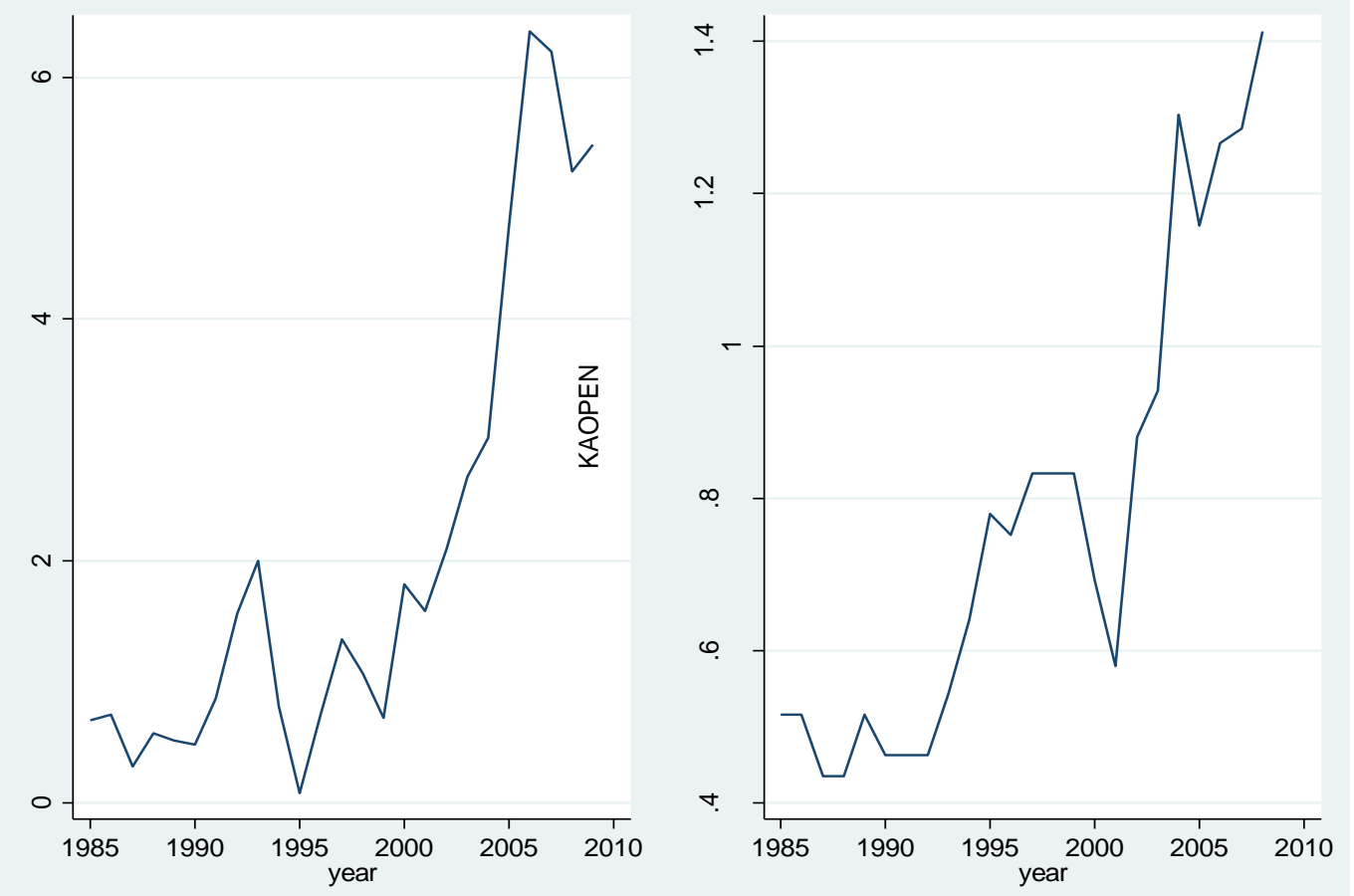

Figure 1. FDI net inflows (\%GDP) and capital openness index, 1985-2009. Source: World Development Indicators and author's calculations, Chinn and Ito (2011).

This paper seeks to contribute to this emerging body of knowledge by investigating the possible existence of macroeconomic stability, financial development, and institutional quality threshold effects in the relationship between financial openness and FDI. This paper focused on the two influential articles; the first pivotal article is given by Noy and Vu (2007) and the second article is proposed by Okada (2013). Noy and Vu (2007) constructed an annual panel dataset for 62 developing and 21 developed countries from 1984 to 2000 and an empirical analysis for each group separately, given that the factors that affect FDI inflows are different across the two groups, using a standard FDI determination model with fixed effect and adding the capital control variable. Furthermore, in order to examine whether the impact of capital controls on FDI inflows is sensitive to different institutional factors like corruption, financial risk, and political stability, they included interaction terms between capital openness and corruption. They underlined that the liberalization of the capital account is not sufficient to generate increases in inflows unless it is accompanied by a lower level of corruption or a 
decrease in political risk. These results are obtained by using fixed effects and least squares estimators and confirmed by GMM dynamic two-step panel estimator. Okada (2013) used a dynamic panel model to examine how financial openness and institutional quality affect international capital inflows in the sample of 112 countries from 1985 to 2009 . He found that while financial openness and institutional quality do not individually have significant impacts on international capital inflows, their interaction effects are significant. He confirmed the assumption that the partial effect of capital openness on FDI inflows is depending on the level of institutional quality and concluded that capital account openness improves FDI inflow only in countries with good institutional quality comparing to those with poor institutional quality. Furthermore, among institutional factors, bureaucratic quality and law and order appear to play an important role in promoting FDI.

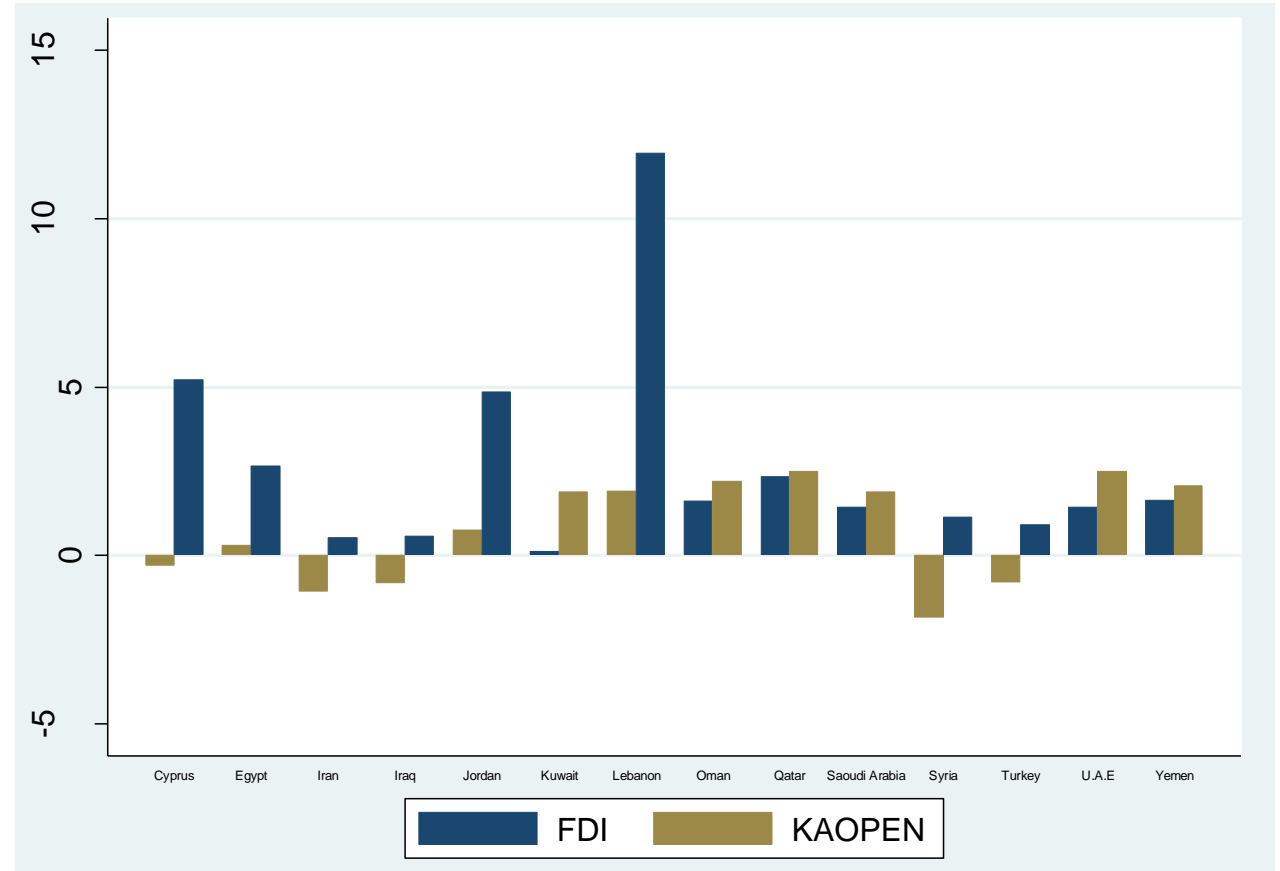

Figure 2. FDI net inflows (\%GDP) and capital openness index in Middle East countries, 1985-2009 (Average). Source: World Development Indicators and author's calculations, Chinn and Ito (2008).

This paper complements previous studies that test the effects of CAL on FDI (Asiedu \& Lien, 2004; Alfaro, Chanda, Kalemli-Ozcan, \& Sayek, 2004; Okada, 2013; Noy \& Vu, 2007) and differs from researches of Noy and Vu (2007) and Okada (2013) in two respects. Firstly, while Noy and Vu (2007) examined only one aspect of institutional quality (corruption) and disregarded the role of other institutional quality which may be important determinants of international capital inflows, this analysis is more comprehensive because the measures of institutional quality reflect several characteristics of a country's institutions, such as the bureaucratic quality, law and order, government stability and investment profile. The second difference is that although Okada (2013) disentangled how detailed components of institutions such as bureaucratic quality and law and order can influence capital inflows, he disregarded the main role of financial development and macroeconomic stability in promoting FDI. This study looks on the interaction effects between capital openness and financial development on FDI inflows. The main contribution of the study is to investigate the possible existence of macroeconomic stability, financial development, and institutional quality threshold effects in the relationship between financial openness and FDI. 
Authors employ a panel data of 14 Middle East countries ${ }^{1}$ over the period from 1985 to 2009. Several studies have found that lagged FDI is correlated with current FDI. Authors therefore use the system GMM methodology for dynamic panel data proposed by Blundell and Bond (1998). This dynamic panel approach enables to consider the presence of unobserved country-specific effects as well as to deal with the problem of reverse causality or simultaneity ${ }^{2}$.

The remainder of the paper is organized as follows: Section 2 presents the empirical methodology and data, Section 3 discusses estimation results, and section 4 concludes the paper.

\section{Empirical Methodology and Data}

\section{Empirical Methodology}

This paper uses a panel of 14 countries from the Middle East region, covers the period from 1985 to 2009, and considers the following benchmark regression presented by Okada (2013):

$$
\mathrm{FDI}_{i t}=\beta_{i}+\beta_{1} \mathrm{KAOPEN}_{i t}+\rho \mathrm{FDI}_{i t-1}+\beta^{\prime} C V_{i t}+\varepsilon_{i t}
$$

where $i$ refers to countries, $t$ refers to time, $\beta_{i}$ is the country-specific effect, and $\varepsilon_{i t}$ is the error term for each observation. FDI is net FDI/GDP, FDI $_{i t-1}$ is the lagged value, KAOPEN is the indicator of CAL developed by Chinn and Ito $(2008)^{3}, C V$ is a vector of controlling variables drawn from the empirical literature of FDI determinants. According to Moosa and Cardak (2006), market size (GDPpc), trade openness (Open) and infrastructure quality (Tele) are the most robust determinants of FDI, thus these variables form part of the basic set of controlling variables and appear in all model specifications. Economic literature suggests that countries which are endowed with natural resources would receive more FDI. This paper therefore includes the share of fuel in total merchandise exports to capture the availability of natural resource endowments (Nat). This measure of natural resources has been employed in several studies, including Jeffrey and Andrew (1997) and Asiedu and Lien (2011) among others and those which are available at World Development Indicators from World Bank.

Furthermore, in order to examine whether CAL promotes FDI only under certain conditions such as macroeconomic stability, financial depth, and political stability, this paper introduces multiplicative terms $($ KAOPEN $* k$ ) where $k$ represents respectively inflation consumer price (INF), financial development (DC), and institutional quality (INST). Therefore, KAOPEN $\times$ INF is the interaction between capital openness and inflation consumer price, KAOPEN*DC is the interaction between capital openness and private credit to the domestic sector, and KAOPEN*INST is the interaction between capital openness and institutional quality.

$$
\mathrm{FDI}_{i t}=\beta_{i}+\beta_{1} \mathrm{KAOPEN}_{i t}+\rho \mathrm{FDI}_{i t-1}+\beta_{2} k_{i t}+\beta_{3}\left(\mathrm{KAOPEN}_{i t} \times k_{i t}\right)+\beta^{\prime} C V_{i t}+\varepsilon_{i t}
$$

As previously mentioned, equations (1) and (2) make up a dynamic panel data model, where the dependent variable is partly explained by its past value. This model involves two econometric problems. The first one results from the dynamic nature of the data, which can introduce some correlations between the lagged depended variable and the error term $\varepsilon_{i t}$ or between some of the variables of the $C V$ vector and the specific term $\beta_{i}$. The second issue results from the potential endogeneity of the explanatory variables. So, the application of static panel data estimation methods would lead to biased estimates with dynamic panel data models. Considering

\footnotetext{
${ }^{1}$ Cyprus, Egypt Arab Republic, Iran Islamic Republic, Iraq, Jordan, Kuwait, Lebanon, Oman, Qatar, Saudi Arabia, Syrian Arab Republic, Turkey, United Arab Emirates, and Yemen.

${ }_{2}$ The system GMM estimation allows to control for the potential endogeneity not only of FDI, but also of all other explanatory variables.

${ }^{3}$ This paper uses the KAOPEN index updated to 2011 which covers 181 countries from 1970 to 2011.
} 
these aspects, the appropriate methodology to use is the GMM estimator for dynamic panel data models suggested by Arellano and Bond (1991), which provides consistent estimates for such models. This estimator often referred to the difference, as GMM estimator takes the first difference of the data and then uses lagged values of the endogenous variables as instruments. This allows to get rid of country specific effects and eliminates any endogeneity that may be caused by the correlation of these country specific effects and the explanatory variables.

This paper therefore lagged independent and control variables for one period, the first difference transforms the first equation (1):

$$
\begin{gathered}
\Delta \mathrm{FDI}_{i t}=\beta_{1} \Delta \mathrm{KAOPEN}_{i t}+\rho \Delta \mathrm{FDI}_{i t-1}+\beta^{\prime} \Delta C V_{i t}+\Delta \varepsilon_{i t} \\
\mathrm{FDI}_{i t}-\mathrm{FDI}_{i t-1}= \\
\beta_{1}\left(\mathrm{KAOPEN}_{i t}-\mathrm{KAOPEN}_{i t-1}\right)+\rho\left(\mathrm{FDI}_{i t-1}-\mathrm{FDI}_{i t-2}\right)+\beta^{\prime}\left(C V_{i t}-C V_{i t-1}\right)+\left(\varepsilon_{i t}-\varepsilon_{i t-1}\right)
\end{gathered}
$$

Consequently, the GMM difference has eliminated the country fixed effect. However, the first-differencing equation (1) induces a new bias by constructing the new error term $\Delta \varepsilon_{i}$, which is correlated with the lagged dependent variable $\Delta \mathrm{FDI}_{i t}$, therefore suggests the following moment conditions:

$$
\begin{aligned}
& \mathrm{E} \times\left[\mathrm{FDI}_{i t-s} \times\left(\varepsilon_{\mathrm{i}}-\varepsilon_{i t-1}\right)\right]=0, \text { for } \mathrm{s} \geq 2 ; \mathrm{t}=1 \ldots, \mathrm{T} ; \\
& \mathrm{E} \times\left[\mathrm{KAOPEN}_{i t-s} \times\left(\varepsilon_{\mathrm{i}}-\varepsilon_{i t-1}\right)\right]=0, \text { for } \mathrm{s} \geq 2 ; \mathrm{t}=1 \ldots, \mathrm{T} ; \\
& \mathrm{E} \times\left[C V_{i t-s} \times\left(\varepsilon_{\mathrm{i}}-\varepsilon_{i t-1}\right)\right]=0, \text { for } \mathrm{s} \geq 2 ; \mathrm{t}=1 \ldots, \mathrm{T} .
\end{aligned}
$$

However, as pointed out by Arellano and Bover (1995), when the explanatory variables are persistent time, lagged levels are often poor instruments for first differences. Blundell and Bond (1998) proposed a more efficient estimator, the system GMM estimator, which mitigates the poor instruments problem by using additional moment conditions. In the Blundell and Bond's GMM estimator, the instruments for the regression in levels are the lagged differences of the corresponding variables and the instruments for the regression in differences are the lagged levels. Thus, Blundell and Bond (1998) and Arellano and Bover (1995) set the following additional moment conditions:

$$
\begin{aligned}
& \mathrm{E} \times\left[\left(\mathrm{FDI}_{i t-s}-\mathrm{FDI}_{\mathrm{i}, \mathrm{t}-\mathrm{s}}\right) \times\left(\beta_{i}+\varepsilon_{i t}\right)\right]=0, \text { for } s=1 ; \\
& \mathrm{E} \times\left[\left(\mathrm{KAOPEN}_{i t-s}-\mathrm{KAOPEN}_{i t-s}\right) \times\left(\beta_{i}+\varepsilon_{i t}\right)\right]=0, \text { for } s=1 ; \\
& \mathrm{E} \times\left[\left(C V_{i t-s}-C V_{i t-s}\right) \times\left(\beta_{i}+\varepsilon_{i t}\right)\right]=0, \text { for } s=1 .
\end{aligned}
$$

In the study, it uses the system GMM approach which generally produces more efficient and precise estimates compared to difference GMM by improving precision and reducing the finite sample bias (Baltagi, 2008).

To verify the consistency of the GMM estimator, authors consider two specification tests: first, the Hansen test ( $J$-test) for over-identifying restrictions. The hypothesis being tested is that the chosen instruments are uncorrelated with the residuals. If the null hypothesis is not rejected, the instruments are valid. Second, the Arellano-Bond test for autocorrelation examines the null hypothesis of no order serial correlation in the first-differenced residuals. Authors check for second-order correlation $\operatorname{AR}(2)^{4}$ which should be not rejected the null hypothesis.

\section{Data}

Data on dependent variable (FDI/GDP) and control variables, including trade openness (\% GDP), GDP per capita (current U.S. dollars.), the number of telephone lines per 1,000 inhabitants, inflation consumer price

\footnotetext{
${ }^{4}$ By construction, the differenced error term is probably first order serially correlated, even if the original error term is not.
} 
(annual \%), domestic credit to the private sector (\% GDP), and natural resource availability (share of fuel in total merchandise exports) were collected from World Development Indicators published by the World Bank (2011). Data on institutional quality were from the International Country Risk Guide (ICRG) published by the Political Risk Services (PRS Group). ICRG ranges from zero to 100, the highest overall rating (theoretically, 100 ) indicates the lowest risk and the lowest score (theoretically, 0) indicates the highest risk. Furthermore, this paper examines five unbundling institutional qualities among the subcomponents of political risk rating: government stability, investment profile, corruption, law and order and bureaucracy quality. To ensure an easier interpretation of the results, all indicators have been re-scaled to $0-1$. The capital control measure (KAOPEN) was taken from Chinn and Ito (2008) and updated to 2011. It is scaled in the range between -2.5 and 2.5, with higher values standing for larger degrees of financial openness. One of the merits of the KAOPEN index is that it refers to the intensity of capital controls, because it incorporates other types of restrictions such as current account restrictions, not just capital account controls. The data were available for 181 developed and developing countries from 1970 to 2008. Noting that the number of observations among countries is not steady, it leads to an unbalanced panel data. Details on the variable definitions and data sources are available in Appendix (Table A1 and A2).

\section{Threshold Condition}

The threshold effects are computed by using the partial differentiation of FDI on KAOPEN:

$$
\frac{\partial \mathrm{FDI}_{t}}{\partial \mathrm{KAOPEN}_{t}}=\beta_{1}+\beta_{3} k_{t}
$$

The positive effect of capital openness on FDI inflows is observed when:

$$
\beta_{1}+\beta_{3} k_{t}>0
$$

Thus, the threshold effects in Middle Eastern countries can be computed as:

$$
k_{t}>-\frac{\beta_{1}}{\beta_{3}}
$$

The presence of the lagged depended variable in the model means that all the estimated beta coefficients represent short period effects. The long period effects can be derived by dividing each of the betas by 1-, the coefficient of the lagged depended variable.

\section{Estimation Results}

\section{Descriptive statistics}

Table 1 summarizes the descriptive statistics from the sample. For all variables, the cross-country variation is very large, except openness to trade. The average of net inflows of FDI is $2.17 \%$ of GDP, with a standard deviation of 3.66. The minimum value of net inflows of FDI concerns Yemen (-5.11 in 1995), whereas the maximum value is for Jordan (23.53 in 2006). Concerning financial development, this paper observes that average of domestic credit to the private sector is 45.66 , with a standard deviation of 42.94 . The minimum reaches 1.8 (Iraq in 2004) and the maximum 269.66 (Cyprus in 2009). Macroeconomic instability seems critical since the average of the annual percentage change of consumer prices equals to 12.75 , with a standard deviation of 20.5. The minimum value goes to Oman (-4 in 1987) and the maximum to Lebanon (99.8 in 1992). Cyprus exhibits the highest value of institutional quality (highest scoring: 0.82), whereas the lowest index value is observed in the Lebanon (lowest scoring: 0.1). 
Table 1

\begin{tabular}{|c|c|c|c|c|c|}
\hline Variable & Obs & Mean & Std. Dev. & Min & Max \\
\hline FDI & 318 & 2.17 & 3.66 & -5.11 & 23.53 \\
\hline KAOPEN & 320 & 0.78 & 1.71 & -1.83 & 2.5 \\
\hline Open & 271 & 78.65 & 32.10 & 5.39 & 170.64 \\
\hline INF & 270 & 12.75 & 20.50 & -4 & 99.80 \\
\hline DC & 323 & 45.66 & 42.94 & 1.8 & 269.66 \\
\hline LGDPpc & 264 & 8.19 & 1.14 & 6.09 & 10.30 \\
\hline LTle & 347 & 2.49 & 0.79 & 0.52 & 3.86 \\
\hline Nat & 266 & 50.64 & 39.72 & 0.0003 & 99.73 \\
\hline INST & 345 & 0.595 & 0.142 & 0.10 & 0.82 \\
\hline GS & 332 & 0.67 & 0.19 & 0 & 0.95 \\
\hline IP & 334 & 0.58 & 0.21 & 0 & 1 \\
\hline COR & 331 & 0.42 & 0.14 & 0.16 & 0.83 \\
\hline LO & 331 & 0.61 & 0.21 & 0.16 & 1 \\
\hline BQ & 331 & 0.48 & 0.20 & 0 & 1 \\
\hline
\end{tabular}

Notes. Open: trade openness; infrastructure quality: Tele; INF: consumer price index; DC: domestic credit to the private sector, LGDPpc $=\log$ (current U.S. dollars), Ltl = Log $(1+$ number of telephone lines per 1,000 inhabitants); Nat: natural resource; INST: political risk; GS: government stability; IP: investment profile; COR: corruption; LO: law and order; and BQ: bureaucracy quality.

In the following, this paper reports results of the estimation using the system GMM estimator. Before discussing the estimation results, the validity of the instruments must be confirmed. Indeed, the GMM system regressions satisfy both the Hansen test of over-identifying restrictions and the second serial correlation test. In all specifications of the Hansen test, this paper does not reject the null hypothesis that the instruments are valid. Moreover, the $\operatorname{AR}(2)$ test fails to reject the null hypothesis that there is no second order correlation in the first-differenced residuals. Then, the model seems correctly specified.

In Table 2, authors present results in which they take into consideration for macroeconomic instability (as measured by inflation consumer price) and financial depth (as measured by domestic credit to private sector). Table 3 provides results when taking into account of the institutional quality index. Table 4 summarizes the results from the regressions running with five of the sub-components of the institutional quality index: law and order, bureaucratic quality, corruption, government stability and investment profile both individually and interactively.

\section{Capital Account Policy, Macroeconomic Stability, Financial Development, and FDI}

Column (1) in Table 2 shows the results of the benchmark equation where KAOPEN is the only explanatory variable, authors control for lagged FDI, market size, trade openness, natural resource, and infrastructure quality. It can be noted that $\partial \mathrm{FDI} / \partial \mathrm{KAOPEN}=\beta_{1}$ and therefore the parameter of interest is the estimated coefficient of KAOPEN, $\beta_{1}$, which is negative and significant at the $10 \%$ level suggesting that all else equal, CAL has an adverse effect on FDI. One standard deviation increase in KAOPEN ( $\mathrm{sd}=1.71$, see Table 1$)$ is expected to decrease FDI by about $1.52 \%$ points [OFDI/ $\partial \mathrm{KAOPEN}=-0.892 \times 1.71=-1.52$ ]. This paper uses an example to provide the reader with a better sense of the negative effect of KAOPEN on FDI in the region. Specifically, it considers two countries in the Middle East countries that have extremely different levels of capital openness Syria, and has the least capital openness country in the Middle East region and Qatar that has 
the highest capital openness. The average value of KAOPEN from 1985 to 2009 is about -1.83 in Syria and 2.5 for in Qatar. Then, the estimation result of the regression (Column 1) shows that all else equal, an increase in KAOPEN from the level of Syria to the level of Qatar will increase FDI by about 3.86\% points in the short run and by about $17.78 \%$ points in the long run. This follows from the fact that the short-run effect of a $\Delta$ change in KAOPEN on FDI is given by $\left(\beta_{1} \times \Delta\right)$ and the long-run effect is $\left(\beta_{1} \times \Delta\right) /(1-\rho)$ : Where is $\beta_{1}$ the estimated coefficient of KAOPEN and $\rho$ is the estimated coefficient of FDI $_{i t-1}$. Here, $\Delta=[2.5-(-1.83)]$ and from Table 2 $\beta_{1}=-0.892$ and $\rho=0.783$, then $\partial \mathrm{FDI} / \partial \mathrm{KAOPEN}=[-0.892 \times(2.5-(-1.83)=-3.86]$ in the short period and 92.4 $[-0.892 \times(2.5-(-1.83)) /(1-0.783)=-17.78]$ in the long period.

In column (2), KAOPEN is interacting with a MENA dummy to test whether the effects of KAOPEN variable on FDI are the same for both MENA and non-MENA countries. It takes the value of one if the country is located in the MENA and zero otherwise. It finds that the coefficient of the interaction terms is negative and insignificant, that is to say that there is no difference between MENA and non-MENA countries in how capital account openness affects FDI inflows.

Table 2

First Differences GMM Estimates: Capital Account Liberalization, Macroeconomic Stability and FDI From 1985 to 2009

\begin{tabular}{|c|c|c|c|c|c|c|}
\hline Variables & $(1)$ & (2) & (3) & (4) & $(5)$ & $(6)$ \\
\hline Lagged FDI & $\begin{array}{c}0.783 \\
(0.078)^{*}\end{array}$ & $\begin{array}{l}0.864 \\
(0.000)^{* * *}\end{array}$ & $\begin{array}{l}0.688 \\
(0.004)^{* * *}\end{array}$ & $\begin{array}{c}0.932 \\
(0.000)^{* * *}\end{array}$ & $\begin{array}{c}0.952 \\
(0.000)^{* * *}\end{array}$ & $\begin{array}{l}0.750 \\
(0.000)^{* * *}\end{array}$ \\
\hline LGDPpc & $\begin{array}{c}0.519 \\
(0.313)\end{array}$ & $\begin{array}{l}-0.347 \\
(0.514)\end{array}$ & $\begin{array}{l}-0.341 \\
(0.019)^{* *}\end{array}$ & $\begin{array}{l}-0.521 \\
(0.005)\end{array}$ & $\begin{array}{l}-0.321 \\
(0.007)^{* * *}\end{array}$ & $\begin{array}{l}-0.981 \\
(0.015)^{* *}\end{array}$ \\
\hline Open & $\begin{array}{l}0.019 \\
(0.033)^{* *}\end{array}$ & $\begin{array}{l}0.016 \\
(0.031)^{* *}\end{array}$ & $\begin{array}{r}0.005 \\
(0.99)\end{array}$ & $\begin{array}{c}0.004 \\
(0.521)\end{array}$ & $\begin{array}{c}0.007 \\
(0.249)\end{array}$ & $\begin{array}{c}0.007 \\
(0.190)\end{array}$ \\
\hline LTel & $\begin{array}{l}-0.253 \\
(0.663)\end{array}$ & $\begin{array}{c}0.258 \\
(0.378)\end{array}$ & $\begin{array}{l}0.35 \\
(0.021)^{* *}\end{array}$ & $\begin{array}{l}0.579 \\
(0.003)^{* * *}\end{array}$ & $\begin{array}{c}0.071 \\
(0.753)\end{array}$ & $\begin{array}{l}-0.05 \\
(0.889)\end{array}$ \\
\hline KAOPEN & $\begin{array}{l}-0.892 \\
(0.062)^{*}\end{array}$ & & & $\begin{array}{c}0.20 \\
(0.126)\end{array}$ & & $\begin{array}{l}-0.981 \\
(0.015)^{* *}\end{array}$ \\
\hline INF & & & $\begin{array}{l}-0.021 \\
(0.062)^{*}\end{array}$ & $\begin{array}{l}-0.003 \\
(0.827)\end{array}$ & & \\
\hline Nat & $\begin{array}{c}0.0014 \\
(0.873)\end{array}$ & $\begin{array}{l}-0.001 \\
(0.755)\end{array}$ & $\begin{array}{l}-0.014 \\
(0.154)\end{array}$ & $\begin{array}{l}-0.006 \\
(0.268)\end{array}$ & $\begin{array}{c}0.001 \\
(0.661)\end{array}$ & $\begin{array}{c}0.011 \\
(0.058)^{*}\end{array}$ \\
\hline INF*KAOPEN & & & & $\begin{array}{c}0.008 \\
(0.589)\end{array}$ & & \\
\hline $\mathrm{DC}$ & & & & & $\begin{array}{l}0.014 \\
(0.002)^{* * *}\end{array}$ & $\begin{array}{l}0.032 \\
(0.030)^{* *}\end{array}$ \\
\hline DC*KAOPEN & & & & & & $\begin{array}{l}0.020 \\
(0.030)^{* *}\end{array}$ \\
\hline MENA*KAOPEN & & $\begin{array}{l}-0.001 \\
(0.998)\end{array}$ & & & & \\
\hline Serial correlation test $(p \text {-value })^{\mathrm{a}}$ & $p=0.48$ & $p=0.5$ & $p=0.66$ & $p=0.61$ & $p=0.67$ & $p=0.49$ \\
\hline Hansen $\mathrm{J}$ test $(p \text {-value })^{\mathrm{b}}$ & $p=0.5$ & $p=0.5$ & $p=0.87$ & $p=0.61$ & $p=0.86$ & $p=0.78$ \\
\hline Number of instruments & 9 & 10 & 9 & 11 & 9 & 12 \\
\hline Countries & 14 & 14 & 14 & 14 & 14 & 14 \\
\hline Observations & 186 & 186 & 171 & 169 & 188 & 186 \\
\hline Mean & & & 12.75 & & 45.66 & \\
\hline Threshold Level & & & & & & 49 \\
\hline
\end{tabular}

Notse. $P$-values are in parenthesis; the dependent variable is FDI/GDP; the data on the political risk note index is normalized to lie between zero and one; a higher number implies more stability; the model is estimated with the two-step Arellano-Bond GMM dynamic panel methodology which is asymptotically efficient and robust for all kinds of heteroskedasticity; ***, **, and * refer to the 1,5, and $10 \%$ levels of significance respectively; ${ }^{\mathrm{a}}$ The null hypothesis is that the errors in the first difference regression exhibit no second order correlation; ${ }^{\mathrm{b}}$ The null hypothesis is that the instruments are not correlated with the residuals. 
Table 3

First Differences GMM Estimates: Capital Account Liberalization, Political Stability and FDI From 1985 to 2009

\begin{tabular}{|c|c|c|}
\hline Dependent variable: FDI/GDP & (1) & $(2)$ \\
\hline \multirow{2}{*}{ Lagged FDI } & 0.816 & 0.767 \\
\hline & $(0.000)^{* * *}$ & $(0.029)^{* *}$ \\
\hline \multirow{2}{*}{ LGDPpc } & -0.378 & 0.215 \\
\hline & $(0.007)^{* * *}$ & $(0.628)$ \\
\hline \multirow{2}{*}{ Open } & 0.014 & -0.015 \\
\hline & $(0.007)^{* * *}$ & $(0.412)$ \\
\hline \multirow{2}{*}{ LTel } & 0.237 & 0.713 \\
\hline & $(0.192)$ & $(0.533)$ \\
\hline \multirow{2}{*}{ Nat } & -0.005 & -0.016 \\
\hline & $(0.330)$ & $(0.176)$ \\
\hline \multirow{2}{*}{ KAOPEN } & & -13.989 \\
\hline & & $(0.007)^{* * *}$ \\
\hline \multirow{2}{*}{ INST } & 2.43 & 0.867 \\
\hline & $(0.060)^{*}$ & $(0.901)$ \\
\hline \multirow{2}{*}{ INST*KAOPEN } & & 22.44 \\
\hline & & $(0.007)^{* * *}$ \\
\hline Serial correlation test $(p \text {-value })^{\mathrm{a}}$ & $P=0.6$ & $P=0.58$ \\
\hline Hansen $J$-test $(p \text {-value })^{\mathrm{b}}$ & $P=0.34$ & $P=0.39$ \\
\hline Number of instruments & 9 & 12 \\
\hline Countries & 14 & 14 \\
\hline Observations & 188 & 186 \\
\hline Mean & & 0.59 \\
\hline Threshold Level & & 0.62 \\
\hline
\end{tabular}

Notes. $P$-values are in parenthesis; the dependent variable is FDI/GDP; the data on the political risk note index is normalized to lie between zero and one; a higher number implies more stability; the model is estimated with the two-step Arellano-Bond GMM dynamic panel methodology which is asymptotically efficient and robust for all kinds of heteroskedasticity; ***, **, and * refer to the 1, 5, and $10 \%$ levels of significance respectively; a. The null hypothesis is that the errors in the first difference regression exhibit no second order correlation; $b$. The null hypothesis is that the instruments are not correlated with the residuals.

This paper now discusses the direct effect of macroeconomic instability and the level of financial development in the host country on FDI. In column (3) and (5), it includes separately the consumer price index (INF) and the domestic credit to the private sector (DC) as explanatory variables. As seen that, while the inflation coefficient is negative and significant at the $10 \%$ level, the estimated coefficient of financial development is positive and significant at the $1 \%$ level, indicating a partial support for the standard proposition that a higher domestic credit increases the FDI inflows, then financial development promotes FDI in Middle East region.

On one hand, column 3 shows that all else equal, a one standard deviation increase in INF $(\mathrm{sd}=20.5$ see Table 1$)$ will decrease FDI by about $0.43 \%$ points $(\partial \mathrm{FDI} / \partial \mathrm{INF}=-0.021 \times 20.5=-0.43)$. On the other hand, column 5 shows that all else equal, a one standard deviation increase in DC ( $\mathrm{sd}=42.94$, see Table 1$)$ will increase FDI by about $0.6 \%$ points $(\partial \mathrm{FDI} / \partial \mathrm{DC}=0.014 \times 42.94=0.6)$. Here, it provides an example to illustrate the catalyzing and direct effect of financial development on FDI. Considering two countries in the Middle East that differ significantly in terms of financial development, Iraq, a country with very poor financial development and Cyprus, a country with the best financial development in Middle East, the average values of the measures of financial (domestic credit to the private sector) from 1985 to 2009 for the two countries are 3.66 in Iraq and Cyprus in 156.56 (Table 5). Then all else equal, an improvement in the financial development of the level of 
Iraq to the level of Cyprus will increase FDI by about $2.14 \%$ points $[0.014 \times(156.56-3.66)=2.14]$. Ali, Fiess, and MacDonald (2010) claimed that macroeconomic stability reduces the level of uncertainty encountered by investors and increases the level of confidence in the economy, which encourages FDI.

Table 4

First Differences GMM Estimates: Capital Account Liberalization, Institutional Quality and FDI From 1985 to 2009

\begin{tabular}{|c|c|c|c|c|c|}
\hline Dependent variable: FDI/GDP & Law and order & Bureaucracy quality & Corruption & $\begin{array}{l}\text { Government } \\
\text { stability }\end{array}$ & $\begin{array}{l}\text { Investment } \\
\text { profile }\end{array}$ \\
\hline Lagged FDI & $\begin{array}{l}0.603 \\
(0.000)^{* * *}\end{array}$ & $\begin{array}{l}0.970 \\
(0.001)^{* *}\end{array}$ & $\begin{array}{l}0.922 \\
(0.002)^{* * *}\end{array}$ & $\begin{array}{c}0.562 \\
(0.095)^{*}\end{array}$ & $\begin{array}{l}0.430 \\
(0.021)^{* *}\end{array}$ \\
\hline LGDPpc & $\begin{array}{l}-1.50 \\
(0.006) * * *\end{array}$ & $\begin{array}{l}-0.163 \\
(0.798)\end{array}$ & $\begin{array}{l}-0.187 \\
(0.771)\end{array}$ & $\begin{array}{c}0.672 \\
(0.517)\end{array}$ & $\begin{array}{l}-1.012 \\
(0.149)\end{array}$ \\
\hline Open & $\begin{array}{l}0.024 \\
(0.074)^{*}\end{array}$ & $\begin{array}{c}0.013 \\
(0.427)\end{array}$ & $\begin{array}{c}0.006 \\
(0.553)\end{array}$ & $\begin{array}{l}-0.00 \\
(0.958)\end{array}$ & $\begin{array}{l}-0.002 \\
(0.820)\end{array}$ \\
\hline LTel & $\begin{array}{l}1.637 \\
(0.047)^{* *}\end{array}$ & $\begin{array}{c}0.307 \\
(0.800)\end{array}$ & $\begin{array}{c}0.108 \\
(0.225)\end{array}$ & $\begin{array}{c}0.478 \\
(0.471)\end{array}$ & $\begin{array}{l}0.16 \\
(0.001)^{* * * *}\end{array}$ \\
\hline KAOPEN & $\begin{array}{l}-5.25 \\
(0.033)^{* *}\end{array}$ & $\begin{array}{l}-7.94 \\
(0.012) * *\end{array}$ & $\begin{array}{l}-4.53 \\
(0.02)^{* *}\end{array}$ & $\begin{array}{l}-7.88 \\
(0.067)^{*}\end{array}$ & $\begin{array}{l}-2.90 \\
(0.044) * *\end{array}$ \\
\hline Nat & $\begin{array}{l}-0.008 \\
(0.392)\end{array}$ & $\begin{array}{l}-0.016 \\
(0.383)\end{array}$ & $\begin{array}{c}0.012 \\
(0.532)\end{array}$ & $\begin{array}{l}-0.005 \\
(0.747)\end{array}$ & $\begin{array}{l}-0.014 \\
(0.235)\end{array}$ \\
\hline INST & $\begin{array}{c}0.561 \\
(0.856)\end{array}$ & $\begin{array}{l}4.07 \\
(0.576)\end{array}$ & $\begin{array}{l}1.59 \\
(0.750)\end{array}$ & $\begin{array}{l}-3.01 \\
(0.552)\end{array}$ & $\begin{array}{l}-1.03 \\
(0.676)\end{array}$ \\
\hline $\mathrm{INST} \times \mathrm{KAOPEN}$ & $\begin{array}{l}8.20 \\
(0.029)^{* *}\end{array}$ & $\begin{array}{l}15.23 \\
(0.009) * * *\end{array}$ & $\begin{array}{l}9.78 \\
(0.009) * * *\end{array}$ & $\begin{array}{l}10.47 \\
(0.05)^{* *}\end{array}$ & $\begin{array}{l}5.44 \\
(0.024)^{* *}\end{array}$ \\
\hline Serial correlation test ( $p$-value $)^{\mathrm{a}}$ & $p=0.27$ & $p=0.18$ & $p=0.71$ & $p=0.3$ & $p=0.86$ \\
\hline Hansen $\mathrm{J}$ test $(p \text {-value })^{\mathrm{b}}$ & $p=0.86$ & $p=0.84$ & $p=0.74$ & $p=0.22$ & $p=0.53$ \\
\hline Number of instruments & 12 & 12 & 11 & 6 & 12 \\
\hline Countries & 14 & 14 & 14 & 14 & 14 \\
\hline Observations & 186 & 186 & 186 & 186 & 186 \\
\hline Mean & 0.61 & 0.48 & 0.42 & 0.67 & 0.58 \\
\hline Threshold Level & 0.64 & 0.52 & 0.46 & 0.75 & 0.53 \\
\hline
\end{tabular}

Notes. $P$-values are in parenthesis; the dependent variable is FDI/GDP; the data on the political risk note index is normalized to lie between zero and one; a higher number implies more stability; the model is estimated with the two-step Arellano-Bond GMM dynamic panel methodology which is asymptotically efficient and robust for all kinds of heteroskedasticity; ***, **, and * refer to the 1,5 , and $10 \%$ levels of significance respectively; ${ }^{a}$ The null hypothesis is that the errors in the first difference regression exhibit no second order correlation; ${ }^{\mathrm{b}}$ The null hypothesis is that the instruments are not correlated with the residuals.

The results so far have shown that CAL and macroeconomic instability undermine FDI and that financial development has had a direct and positive effect on FDI. This paper now tests whether an improvement in financial development will result in a significant reduction in $\partial \mathrm{FDI} / \partial \mathrm{KAOPEN}$. Here, it estimates equation (2) and reports the results also in column 5 (see Table 2).

Noting that $\left[\partial \mathrm{FDI} / \partial \mathrm{KAOPEN}=\beta_{1}+\beta_{3} \times \mathrm{DC}\right]$, the parameters of interest are the estimated coefficient of KAOPEN, $\beta_{1}$, and the estimated coefficient of the interaction term, $\beta_{3}$. Estimations show that $\beta_{1}$ is negative and significant at the $5 \%$ level and $\beta_{3}$ is positive and significant at the 5\% level, suggesting that financial development significantly reduces the adverse effect of capital account openness on FDI.

The marginal impact of KAOPEN is:

$$
\frac{\partial \mathrm{FDI}_{t}}{\partial \mathrm{KAOPEN}_{t}}=-0.981+0.02 \times D C
$$


Table 5

Countries Included in the Regressions

\begin{tabular}{|c|c|c|c|c|c|c|c|c|c|c|c|c|c|c|}
\hline countries & FDI & KAOPEN & Open & LGDPpc & Ltl & Nat & DC & INF & INST & GS & IP & $\mathrm{COR}$ & $\mathrm{LO}$ & BQ \\
\hline$\overline{\text { Cyprus }}$ & 5.2 & -0.31 & 100.14 & 9.32 & 3.62 & 2.57 & 156.56 & 3.42 & 0.71 & 0.68 & 0.80 & 0.67 & 0.73 & 0.90 \\
\hline Egypt & 2.64 & 0.31 & 50.98 & 7.20 & 1.93 & 42.61 & 38.85 & 10.76 & 0.58 & 0.71 & 0.51 & 0.37 & 0.57 & 0.50 \\
\hline Iran & 0.53 & -1.09 & 39.24 & 7.33 & 2.45 & 81.96 & 24.54 & 20.24 & 0.54 & 0.63 & 0.44 & 0.50 & 0.60 & 0.46 \\
\hline Iraq & 0.58 & -0.80 & na & 6.79 & 1.51 & 89.37 & 3.66 & na & 0.33 & 0.53 & 0.39 & 0.25 & 0.27 & 0.10 \\
\hline Jordan & 4.86 & 0.76 & 112.53 & 7.51 & 2.31 & 0.17 & 70.03 & 4.77 & 0.61 & 0.72 & 0.58 & 0.55 & 0.59 & 0.53 \\
\hline Kuwait & 0.13 & 1.89 & 94.17 & 9.71 & 3.03 & 75.8 & 54.41 & 2.54 & 0.65 & 0.66 & 0.67 & 0.45 & 0.71 & 0.48 \\
\hline Lebanon & 11.94 & 1.90 & 71.59 & 8.25 & 2.75 & 0.27 & 68.25 & 26.46 & 0.46 & 0.56 & 0.48 & 0.29 & 0.51 & 0.35 \\
\hline Oman & 1.61 & 2.19 & 85.60 & 8.97 & 2.15 & 83.88 & 30.91 & 1.20 & 0.69 & 0.75 & 0.71 & 0.47 & 0.75 & 0.56 \\
\hline Qatar & 2.34 & 2.50 & 89.02 & na & 3.17 & 86.23 & 38.47 & 3.52 & 0.65 & 0.73 & 0.66 & 0.35 & 0.77 & 0.43 \\
\hline Saoudi Arabia & 1.44 & 1.89 & 72.35 & 9.13 & 2.49 & 89.91 & 26.19 & 0.35 & 0.61 & 0.70 & 0.68 & 0.35 & 0.78 & 0.57 \\
\hline Syria & 1.13 & -1.83 & 62.11 & 7.01 & 2.22 & 59.78 & 10.36 & 12.37 & 0.58 & 0.76 & 0.45 & 0.44 & 0.66 & 0.31 \\
\hline Turkey & 0.92 & -0.78 & 46.41 & 7.96 & 2.99 & 2.38 & 20.20 & 53.70 & 0.57 & 0.63 & 0.55 & 0.45 & 0.62 & 0.56 \\
\hline U.A.E & 1.44 & 2.50 & 132.81 & 10.06 & 3.29 & 49.51 & 52.03 & 3.78 & 0.66 & 0.69 & 0.69 & 0.38 & 0.62 & 0.62 \\
\hline Yemen & 1.63 & 2.06 & 78.48 & 6.22 & 1.05 & 88.57 & 5.88 & 27.96 & 0.60 & 0.73 & 0.58 & 0.43 & 0.42 & 0.35 \\
\hline
\end{tabular}

Notes. na: indicates missing data; Open: trade openness; infrastructure quality: Tele; INF: consumer price index; DC: domestic credit to the private sector, LGDPpc $=\log$ (current U.S. dollars), Ltl = Log $(1+$ number of telephone lines per 1,000 inhabitants); Nat: natural resource; INST: political risk; GS: government stability; IP: investment profile; COR: corruption; LO: law and order; and BQ: bureaucracy quality.

Here again, it uses the sample of Iraq and Cyprus. It notes that the average value of financial development is equal to 3.66 for Iraq and 156.65 for Cyprus. Then, the increase in KAOPEN by one standard deviation will

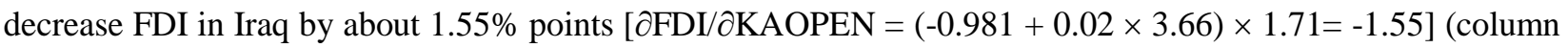
6). Now it supposes that Iraq implements policies lead to an improvement in its financial development, such that the value of financial development increases to the level of Cyprus. Thus, a one standard deviation increase

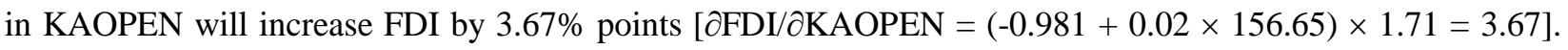
It's important to note that the estimated coefficient of financial development remains significant, suggesting that financial development has a direct and indirect impact on FDI.

The total effect of one unit increase in KAOPEN for the Middle East region is calculated to be $-0.067 \%$ point using the average value of financial development in the Middle East region [OFDI/OKAOPEN $=-0.981+$ $(0.02 \times 45.66)=-0.067]$. The threshold level of financial development, separating negative and positive partial impacts of KAOPEN on FDI inflows, is $49.05\left[-\left(\beta_{1} / \beta_{3}\right)=-(-0.981 / 0.02)=49.05\right]$. Then, it can be concluded that FDI inflows in countries with a sound domestic financial system benefit more from CAL than those in countries with a fragile financial system. It appears that countries should first reform their domestic financial system before liberalizing the capital account to allow for enlarged FDI inflows.

This paper also checks whether the impact of capital control on FDI inflows is sensitive to macroeconomic instability, results show that the coefficient of the interaction term between the two variables is not statistically significant, thus, macroeconomic instability does not seem to further the CAL-FDI relationship. The estimated coefficient of lagged FDI is positive and significant in all regressions, an indication that FDI is persistent. It can be concluded that dynamic GMM is an appropriate estimator (Baltagi, Demetriades, \& Law, 2009). Per capita GDP has perverse signs, showing significant negative effects on FDI inflows. Trade openness, as measured by the trade-GDP ratio, has a positive and significant impact on FDI inflows, supporting the evidence that 
countries that are more open can attract more FDI inflows (Buchanan, Le, \& Rishi, 2012). Results show also that the infrastructure quality as measured by the number of telephone lines per thousand population plays a significant role in absorbing FDI, this result of which is confirmed by Moosa and Cardak (2006) and Ali et al. (2010).

\section{Capital Account Policy, Institutions, and FDI}

Table 3 reports the results of the regression analyzing the direct effect of institutional quality on FDI inflows (column 1) and their influence on the role of capital account policy in promoting FDI inflows (column 2). As shown in column (1), institutional quality plays a significant role in determining FDI inflows by a positive and significant coefficient on the institutional quality variable at the $10 \%$ level $(k=\mathrm{INST})$. This implies that FDI is attracted by the countries where institutions are solid. The result is in line with Ali et al. (2010) who have stressed the importance of institutional quality in determining FDI inflows.

A one standard deviation increase in institutional quality ( $\mathrm{sd}=1.14$, see Table 1$)$ will increase FDI by about $2.77 \%$ points $(\partial \mathrm{FDI} / \partial \mathrm{INST}=2.43 \times 1.14=2.77)$. As a sample, this paper uses again the samples of Cyprus and Iraq, which differ significantly in terms of institutional quality. The average values of the measures of institutional quality from 1985 to 2009 of the two countries are INST -0.71 for Cyprus and 0.33 in Iraq (see Table 5). Then all else equal, an improvement in institutional quality of the level of Iraq to the level of Cyprus will increase FDI by about $0.92 \%$ points in the short period $[2.43 \times(0.71-0.33)=0.92]$ and by about $0.12 \%$ points in the long period $[2.43 \times(0.71-0.33) / 1-0.81=0.12]$.

Then, this paper uses KAOPEN index and its interaction with the institutional quality variable to look for whether institutional quality matters for FDI and CAL relationship. Regression in column (2) indicates that the coefficient of KAOPEN, $\beta_{1}$, is negative and significant at the $5 \%$ level and the estimated coefficient of the interaction term, $\beta_{3}$, is positive, suggesting that institutional quality as financial development significantly reduces the adverse effect of capital account openness on FDI. Thus, the marginal effect of financial openness on FDI increases with institutions, and the threshold level of institutions between the negative and positive partial effect is $0.62(13.989 / 22.44=0.62)$ which is 65 th percentile in this sample. That is to say that, in the sample, at most $35 \%$ (at least $65 \%$ ) of the observations are greater (smaller) than 0.62 . The negative effect of capital openness on FDI in the Middle East countries is significant because of the low level of institutional quality in the region, the average value of institutional quality in Middle East countries is 0.59 (see Table 3) which is lower than the threshold levels (0.62).

Figure 2 presents a visual picture of the marginal effect of KAOPEN on FDI, based on each country's value of the political risk index for the Middle East countries. It indicates that countries, such as Cyprus, Oman, and U.A.E that show positive effects of financial opening, have attained a threshold level of political stability, whereas countries with underdeveloped institutional infrastructure may hamper the FDI inflows. So, the sample countries can be categorized into two: Category A refers to countries where capital openness policy may promote FDI and category B refers to countries where an increase in capital openness may not result in an increase in FDI, and may possibly reduce FDI. Results reveal that $35 \%$ of countries in the sample lie above the threshold of political risk index (0.62) and, then fall in category A, which are Kuwait, Oman, Qatar, U.A.E, and Cyprus and 65\% in the sample lie below the threshold level, which is Egypt, Iran, Iraq, Jordan, Lebanon, Syria, Saudi Arabia, Turkey, and Yemen, these countries fall in category B.

Until now, institutional quality is discussed as a composite index of political risks comprising 12 
subcomponents, Okada (2013) asserted that this index is enabled to capture the appropriate effects on international capital inflows thus, in the following, it is interesting to investigate the impact of the interaction between the five main subcomponents of political risk and capital account openness on FDI inflows. Specifically, it considers bureaucratic quality, law and order, corruption, government stability, and investment profile which may be important determinants of international capital inflows. To ensure easier interpretation, authors standardize all sub-indicators of the institutional index to range between 0 and 1 where a higher value indicates a higher institutional quality, results are reported in Table 4. As seen in all specifications, the coefficient interaction terms between financial openness and each sub-indicators of institutional quality are significantly positive. This seems to confirm the finding and implies that the result is robust, that its institutional quality matters for CAL and FDI inflows relationship, a result which is in the line with previous studies by Noy and Vu (2007) and Okada (2013). However, in all cases, except in the specification where investment profile is used as a proxy of institutional quality, Middle East region seems far from the threshold (mean < threshold level). In panel (3), for example, the one unit increase in KAOPEN for the Middle East region is expected to decrease FDI by $0.42 \%$ points, using the average value of corruption in Middle East $[\partial \mathrm{FDI} / \partial \mathrm{KAOPEN}=-4.53+(9.78 \times 0.42)=-0.42]$. This is due to the high levels of corruption in the region. Thereby, it can suggest that CAL is only efficient in generating more inflows of FDI in an environment of low political risk (Noy \& Vu, 2007).

\section{Conclusions}

By employing the data of 14 Middle East countries over the period from 1995 to 2009, this paper investigates the effect of CAL on FDI inflows, taking into account the role of macroeconomic stability, financial development level and institutional quality in each country. It finds that, while CAL has a negative effect on FDI, good institutions and domestic financial developments (in particular, the domestic credit to private sector) mitigate this adverse effect. It concludes that there are threshold levels of institutional quality and financial development that are important determinants of the relationship between CAL and FDI. The results reveal that capital openness facilities FDI in Kuwait, Oman, Qatar, U.A.E., and Cyprus, where political risk is above the threshold level (0.62), but it has a negative effect on FDI in Egypt, Iran, Iraq, Jordan, Lebanon, Syria, Saudi, Arabia, Turkey, and Yemen, where political risk is high and then below the threshold level. It finds also, that although macroeconomic instability has a negative impact on FDI inflows, it does not seem to further the CAL-FDI relationship.

With regard to policy, the results suggest that capital account policy in Middle East countries must be embedded within a sound institutional and financial framework. Thus, governments in this region should develop a set of policies that are not only focused on capital account openness but also on the improvement of financial institution's efficiency and political framework, which constitutes a necessary precondition for successful the liberalization of the capital account and attracting foreign investors. Egypt, Iran, Iraq, Jordan, Lebanon, Syria, Saudi, Arabia ,Turkey, and Yemen must undertake measures that can help to fight corruption, enhance the protection of property rights, increase the respect for law and the impartiality of the legal system, and improve other aspect of the institutional environment. The results are in line with Okada (2013) and Noy and $\mathrm{Vu}$ (2007) who have stressed the importance of institutional quality in the CAL-FDI nexus. These results have an important implication for countries in Middle East given that most of them are in dire need of FDI with weak institutions. 


\section{References}

Alfaro, L., Chanda, A., Kalemli-Ozcan, S., \& Sayek, S. (2004). FDI and economic growth: The role of local financial markets. Journal of International Economics, 64, 89-112.

Alfaro, L., Kalemli-Ozcan, S., \& Volosovych, V. (2005). Why doesn't capital flow from rich to poor countries? An Empirical Investigation (NBER Working Paper).

Ali, F. A., Fiess, N., \& MacDonald, R. (2010). Do institutions matter for foreign direct investment? Open Economies Review, 21, 201-219.

Arellano, M., \& Bond, S. (1991). Some tests of specification for panel data: Monte carlo evidence and an application to employment equations. The Review of Economic Studies, 58, 277-297.

Arellano, M., \& Bover, O. (1995). Another look at the instrumental variable estimation of error-components models. Journal of Econometrics, 68, 29-51.

Asiedu, E., \& Lien, D. (2004). Capital controls and foreign direct investment. World Development, 32, 479-490.

Asiedu, E., \& Lien, D. (2011). Democracy, foreign direct investment and natural resources. Journal of International Economics, 84, 99-111.

Baltagi, B. (2008). Econometric analysis of panel data. Chichester: John Wiley \& Sons.

Baltagi, B. H., Demetriades, P. O., \& Law, S. H. (2009). Financial development and openness: Evidence from panel data. Journal of Development Economics, 89, 285-296.

Blundell, R., \& Bond, S. (1998). Initial conditions and moment restrictions in dynamic panel data models. Journal of Econometrics, 87, 113-113.

Buchanan, B. G., Le, Q. V., \& Rishi, M. (2012). Foreign direct investment and institutional quality: Some empirical evidence. International Review of Financial Analysis, 21, 81-89.

Butkiewicz, J. L., \& Yanikkaya, H. (2008). Capital account openness, international trade, and economic growth: A cross-country empirical investigation. Emerging Markets Finance and Trade, 44, 15-38.

Cherif, M., Ben N. S., Goaied, M., \& Kamer, B. (2011). Does capital account liberalization spur economic and financial performance? New investigation for mena countries ( No. FEM33-06).

Chinn, M. D., \& Ito, H. (2008). A new measure of financial openness. Journal of Comparative Policy Analysis: Research and Practice, 10, 309-322.

Gastanaga, V. M., Nugent, J. B., \& Pashamova, B. (1998). Host country reforms and FDI inflows: How much difference do they make? World Development, 26, 1299-1314.

Jeffrey, D. S., \& Andrew, M. W. (1997). Natural resource abundance and economic growth. Retrieved from http://www.nber.org/papers/w5398.pdf

Moosa, I. A., \& Cardak, B. A. (2006). The determinants of foreign direct investment: An extreme bounds analysis. Journal of Multinational Financial Management, 16, 199-211.

Noy, I., \& Vu, T. B. (2007). Capital account liberalization and foreign direct investment (Working Paper No. 200708, University of Hawaii at Manoa, Department of Economics).

Okada, K. (2013). The interaction effects of financial openness and institutions on international capital flows. Journal of Macroeconomics, 35, 131-143. 


\section{Appendix}

Table A1

Variables, Definitions and Sources

\begin{tabular}{|c|c|c|}
\hline Variable & Definition & Source \\
\hline FDI & $\begin{array}{l}\text { Foreign direct investment, net inflows (\% of GDP): Foreign direct investment is the net inflows } \\
\text { of investment to acquire a lasting management interest ( } 10 \text { percent or more of voting stock) in } \\
\text { an enterprise operating in an economy other than that of the investor. It is the sum of equity } \\
\text { capital, reinvestment of earnings, other long-term capital, and short-term capital as shown in } \\
\text { the balance of payments. }\end{array}$ & $\mathrm{WDI}^{5}$ \\
\hline GDPpc & $\begin{array}{l}\text { GDP per capita is gross domestic product divided by midyear population. GDP is the sum of } \\
\text { gross value added by all resident producers in the economy plus any product taxes and minus } \\
\text { any subsidies not included in the value of the products. It is calculated without making } \\
\text { deductions for depreciation of fabricated assets or for depletion and degradation of natural } \\
\text { resources. Data are in current U.S. dollars. }\end{array}$ & WDI \\
\hline Open & $\begin{array}{l}\text { Trade is the sum of exports and imports of goods and services measured as a share of gross } \\
\text { domestic product. }\end{array}$ & WDI \\
\hline Tel & $\begin{array}{l}\text { Telephone lines are fixed telephone lines that connect a subscriber's terminal equipment to the } \\
\text { public switched telephone network and that have a port on a telephone exchange. Integrated } \\
\text { services digital network channels and fixed wireless subscribers are included. }\end{array}$ & WDI \\
\hline INF & $\begin{array}{l}\text { Inflation as measured by the consumer price index reflects the annual percentage change in the } \\
\text { cost to the average consumer of acquiring a basket of goods and services that may be fixed or } \\
\text { changed at specified intervals, such as yearly. The Laspeyres formula is generally used. }\end{array}$ & WDI \\
\hline DC & $\begin{array}{l}\text { Domestic credit to private sector (\% of GDP) refers to financial resources provided to the } \\
\text { private sector, such as through loans, purchases of no equity securities, and trade credits and } \\
\text { other accounts receivable that establish a claim for repayment. For some countries these claims } \\
\text { include credit to public enterprises. }\end{array}$ & WDI \\
\hline Nat & Share of fuel in total merchandise exports & WDI \\
\hline KAOPEN & Capital openness index measuring the extent of openness in capital account transactions & Chinn-Ito $^{6}$ \\
\hline INST & $\begin{array}{l}\text { Political risk rating consists of the following } 12 \text { subcomponents: (A) Government Stability } \\
\text { (12points), (B) Socioeconomic Conditions (12points), (C) Investment Profile (12 points), (D) } \\
\text { Internal Conflict (12 points), (E) External Conflict ( } 12 \text { points), (F) Corruption (6 points), (G) } \\
\text { Military in Politics (6 points), (H) Religious Tensions (6 points), (I) Law and Order (6 points), } \\
\text { (J) Ethnic Tensions (6 points), (K) Democratic Accountability (6 points), (L) Bureaucracy } \\
\text { Quality (4points). Institutions which are defined as the sum of each component are ranged from } \\
0 \text { to } 100 \text { and a larger value means lower political risk. }\end{array}$ & PRS-ICRG ${ }^{7}$ \\
\hline
\end{tabular}

\footnotetext{
5 World Development Indicators (2011)

${ }^{6}$ Chinn- Ito (2011)

7 International Country Risk Guide
} 
Table A2

Variables, Definitions and Sources (Continued)

\begin{tabular}{|c|c|c|}
\hline Variable & Definition & Source \\
\hline $\begin{array}{l}\text { Government } \\
\text { Stability }\end{array}$ & $\begin{array}{l}\text { This is an assessment both of the government's ability to carry out its declared programs, } \\
\text { and its ability to stay in office. The risk rating assigned is the sum of three factors } \\
\text { (Government Unity, Legislative Strength Popular Support) each of them with a maximum } \\
\text { score of four points and a minimum score of } 0 \text { points. Thus the government stability } \\
\text { scores from } 0 \text { to } 12 \text { and a higher values corresponding to "low risk levels". }\end{array}$ & PRS-ICRG \\
\hline $\begin{array}{l}\text { Investment } \\
\text { Profile: }\end{array}$ & $\begin{array}{l}\text { This is an assessment of factors affecting the risk to investment that are not covered by } \\
\text { other political, economic, and financial risk components. It is the sum of three } \\
\text { subcomponents (contract viability/ expropriation, profit repartition and payment delays). } \\
\text { Each of them with a maximum score of four points and a minimum score of } 0 \text { points, so, } \\
\text { investment profile measured on a scale of } 0 \text { to } 12 \text {, with } 0 \text { represent the highest risk levels } \\
\text { similarly } 12 \text { represent the lowest risk levels. }\end{array}$ & PRS-ICRG \\
\hline Corruption & $\begin{array}{l}\text { This index aims at evaluating the degree of corruption within the political system. It } \\
\text { indicates the opinion of analysts on each country regarding the extent to which high } \\
\text { government officials are likely to demand special payments, and illegal payments } \\
\text { generally expected throughout lower levels of government in the form of bribes connected } \\
\text { with import and export licenses, exchange controls, tax assessment, policy protection, or } \\
\text { loans. It ranks nations on a scale from } 0 \text { to } 6 \text {. A score of } 0 \text { represents maximum corruption } \\
\text { level, while } 6 \text { indicates minimum corruption level. }\end{array}$ & PRS-ICRG \\
\hline Law and Order & $\begin{array}{l}\text { It ranges from } 0 \text { to } 6 \text {, where a higher number indicates a better system of law and order. } \\
\text { This variable "reflects the degree to which the citizens of a country are willing to accept } \\
\text { the established institutions to make and implement laws and adjudicate disputes". Higher } \\
\text { scores indicate: "sound political institutions, a strong court system, and provisions for an } \\
\text { orderly succession of power". Lower scores indicate: "a tradition of depending on } \\
\text { physical force or illegal means to settle claims". Upon changes in government new leaders } \\
\text { "may be less likely to accept the obligations of the previous regime. }\end{array}$ & PRS-ICRG \\
\hline $\begin{array}{l}\text { Bureaucracy } \\
\text { Quality }\end{array}$ & $\begin{array}{l}\text { It ranges from } 0 \text { to } 4 \text {. High scores indicate "an established mechanism for recruitment and } \\
\text { training", "autonomy from political pressure", and "strength and expertise to govern } \\
\text { without drastic changes in policy or interruptions in government services" when } \\
\text { governments change. }\end{array}$ & PRS-ICRG \\
\hline
\end{tabular}

